\title{
РЕЛИГИОВЕДЕНИЕ
}

\author{
UDC 283(410.1)
}

\section{The Oxford movement studies: Main historiographical problems and trends*}

\author{
M. S. Stetckevich ${ }^{1}$, T. V. Chumakova ${ }^{1}$, S. Frolov ${ }^{2}$ \\ ${ }^{1}$ St. Petersburg State University, \\ 7-9, Universitetskaya nab., St. Petersburg, 199034, Russian Federation \\ ${ }^{2}$ Southern Methodist University, \\ 6424 Robert S. Hyer Lane, Dallas, Texas, 75275, USA
}

For citation: Stetckevich M.S., Chumakova T.V., Frolov S. The Oxford movement studies: Main historiographical problems and trends. Vestnik of Saint Petersburg University. Philosophy and Conflict Studies, 2019, vol. 35, issue 4, pp. 662-673. https://doi.org/10.21638/spbu17.2019.411

The article analyzes the main trends in the historiography of the Oxford (Tractarian) movement in the Church of England, which had a significant impact not only on its subsequent development, but also on the evolution of Anglicanism as a whole. The purpose of the article is to identify the key trends in the development of the historiography of the Oxford movement and to distinguish the range of problems studied by researchers, focusing on the most controversial issues. The article aims to analyze the works of the authors who reviewed the history of the Oxford movement in the context of the evolution of the Church of England (N. Gash, O. Chadwick, P. Avis, S. Brown), and researchers who focused on the phenomenon of Tractarianism itself (M. O’Connell, J. Griffin, J. Rowlands, P. Nockles, J. Pereiro, G. Herring). The authors of the article used problem-chronological and comparative methods, which allow for the presentation of the main historiographical achievements in their dynamic development. It can be concluded that the confessionalism expressed in the representation of the Tractarian leaders either as "saviors" of the Church of England, or as "traitors" who sought to bring it into the bosom of the Roman Catholic Church, has been completely overcome. A significant research consensus was reached on issues such as the date of the movement's origin, its revolutionary nature and connection with the High Church tradition, and the importance of the influence of Tractarianism on the subsequent evolution of Anglicanism. Issues such as the relationship of Tractarianism with the Ritualists movement remains debatable. Further

* This article was completed for the project 18-011-00241 of the Russian Foundation of Basic Research (RFBR) "From erastianism to tractarianism: the Church of England in the late XVIII — first half of the XIX century".

(C) Санкт-Петербургский государственный университет, 2019 
prospects for the study of the Oxford movement primarily concern the study of its perception by British society, and investigation of its international dimension (in particular, Russian).

Keywords: The Oxford movement, Tractarianism, The Church of England, historiography, Anglicanism, religious studies.

\section{Introduction}

The Oxford (Tractarian) movement, developed under the leadership of such divines as J. Keble (1792-1866), R. H. Froude (1803-1836), E. B. Pusey (1800-1882) and especially J. H. Newman $(1801-1890)$, is recognized by the overwhelming majority of researchers as the largest phenomenon in the history of $19^{\text {th }}$ century Anglicanism, and sometimes referred to as one of the most important events in the history of Western Christianity in the past two centuries. Started, according to the traditional opinion, in 1833, the Oxford movement significantly changed the face of the Church of England. Tractarianism raised a number of vital questions: what is Anglicanism, can the Church of England be considered Protestant and / or Catholic, and what is its most important mission? The Oxford movement had a strong influence on the development of church architecture, liturgical forms, and visual arts, eliciting responses not only in various parts of the English-speaking world, but also beyond including Russia.

The bibliography of the movement is enormous [1]. At the same time, the number of works specifically devoted to the problems of the movement's historiography is relatively small. As a rule, they are limited to short historiographical essays. As an exception, we can mention the Ph.D. thesis of V.Santos Sotelo, and historiographic sections in the monographs of P. Nockles and S. Skinner [2; 3, p. 1-43; 4, p. 2-17].

The objectives of the present article are as follows: to characterize the most important trends prevailing in the historiography of the Oxford movement, to highlight the most important issues discussed by historians of Tractarianism, to provide a critical analysis of the most significant works (primarily monographs) and to identify possible prospects for further research.

\section{Confessional trend}

In the preface to his book, which until now has been considered the classic history of the movement, Dean of St. Paul's Cathedral in London R. Church noted: "We are sometimes told that enough has been written about the Oxford movement, and that the world is rather tired of the subject" [5, p. IX-X]. These lines, written in the 1880 s, undoubtedly testify to the presence of considerable interest in Tractarianism in the educated circles of English society.

The first works, which, in spite of their polemicity, can be viewed as histories of the Oxford movement, were the writings of the High churchman W. Palmer's "Narrative of Events connected with the publication of the Tracts for the Times" (1843) and famous autobiography of J.H. Newman "Apologia Pro Vita Sua" (1864). In the first edition of his book Palmer, who was very close to the movement in the early 1830s, sought to show that the initial aspirations of its original participants were aimed only at restoring the Church of England as a sacral institution and did not suggest any convergence with Roman Catholicism [6, p. V-X, 43-46]. In the second edition, published in 1883, Palmer empha- 
sized that the departure of Newman and some other members of the movement (W. Ward, F. Oakeley) to Rome (1845) is the incidental and unnatural product of Tractarianism [7, p. 239-241].

If Palmer's work is a kind of apology for his participation in the Oxford movement, Newman's autobiography is first and foremost an apology for his drift from Anglicanism to Roman Catholicism. Newman points out that he did not set himself the task of writing a history of the Oxford movement [8, p. 108]. At the same time, the history of the movement presented through Newman's eyes is undoubtedly exist in the "Apology". Tractarianism itself is viewed by Newman as the initial stage of his personal struggle against liberalism in its various manifestations [8, p. 146-149].

Also of note is the four-volume biography of E. B. Pusey, written by H.Liddon - a theologian, who shared the main Tractarian views. It contains, like the writings of Palmer and Newman, a huge amount of documentary material and is also both a research work and a source for the study of the Oxford movement [9].

For a long time "the Oxford Movement continued to be a "live" issue with the capacity to elicit strong reactions on either side for several generations after its first inception" [10, p.605]. Up to the beginning of the $20^{\text {th }}$ century, most researches were far from impartial and positioned themselves as supporters or opponents of Tractarianism. The abovementioned R. Church, who was closely allied to the Tractarian movement, laid the foundation for the historiographic trend, according to which the Oxford movement was regarded as the only force that saved the Church of England from spiritual degradation and allowed it to renew and restore itself as a sacral institution.

Church was also the first scholar who tried to define the chronological framework of the Oxford movement. Following Newman, he dated the start of the movement to July 14, 1833 [5, p. 82-84] - the day of the sermon "National Apostasy," preached by J.Keble, in which he stated the existence of serious threats to the Church of England, primarily the distribution of the "unchristian temper," and cautiously called for "remonstrance" against the current situation [11, p. 24-27]. Church relates the end of the movement to 1845 - the moment of Newman's transition to Roman Catholicism. Church called this departure a "catastrophe" [5, p. 385].

The most striking manifestation of the tendency to depict Tractarians as the 'saviors' of the Church of England was the work of S. Ollard. Calling members of the Oxford movement "the most spiritual people who have ever lived in England" [12, p. 1], Ollard categorically rejects the assumption of the original pro-Roman orientation of Tractarianism [12, p.11].

According to him, by 1833 the Church of England "appeared to be nearly spiritually dead" $[12$, p. 16], while the Oxford theologians promoted the revival of the heritage of the undivided Ancient Church. Unlike Church, Ollard does not consider 1845 as the conclusion of the movement. He sees a direct connection between Tractarianism and Ritualism, which appeared in the 1850s and concentrated on the restoration of pre-Reformation liturgical practice [12, p. 95-203].

In parallel with the glorification of the Oxford movement, there was another historiographical tendency: to represent Tractarians as "enemies" who were trying to destroy the Church of England. This tendency is most fully expressed in the writings of W. Walsh $[13 ; 14]$. 
From his point of view, all members of the Oxford movement initially sought to rejoin Rome, and only masked their views [14, p.VII]. Walsh believes that the Oxford movement in fact originated in Rome, basing this conclusion on the fact of the meeting of Newman and Froude with Cardinal N. Wiseman during their trip to the Continent in 1833 [14, p. 19-21].

Many works that appeared in connection with the centenary anniversary of the Oxford movement may be seen as evidence of the dominance of confessionalism in the historiography of Tractarianism up to the middle of the $20^{\text {th }}$ century. The heirs of Tractarians - representatives of the Anglo-Catholic wing in the Church of England continued, following Church and Ollard, to characterize negatively the era preceding the emergence of the movement and appreciate the achievements of Newman and his friends. The titles of some publications are indicative of this: "Heroes of the Catholic Revival" [15], "Studies of the Saints and Heroes of the Oxford Movement" [16].

In turn, in the works of the authors belonging to the opposite, Evangelical wing, Tractarians were characterized, if not as traitors, then as schismatics ${ }^{1}$. They continued to create "anti-histories" of the Tractarianism [10, p. 605].

The researchers who belonged to the Roman Catholic Church also paid attention to the study of the Oxford movement. The eminent English philosopher and historian C. Dawson who moved from Anglicanism to Roman Catholicism in 1914, writes about the Tractarianism with great sympathy. To Dawson, who sharply condemned liberalism and secularization, the position of the Tractarians was ideologically close. Dawson was the first among the scholars of Tractarianism, who paid major attention to such a figure as Froude, considering his influence on Newman decisive [18, p.47-48, 75]. For Roman Catholic Dawson, unlike Palmer and other Anglican authors, the shift of Newman and some of his friends to Rome was a natural and positive phenomenon [18, p. 113-126].

It is not surprising that at this time the view that was least burdened by confessional attachments was offered by an outsider, namely, by the Swedish Lutheran theologian, later Archbishop of Uppsala Y. Brilioth [19]. The merit of Brilioth's work lies in its emphasis on the analysis of the ways in which Tractarianism was influenced not only by the High Church tradition, but also by Evangelism and literary romanticism. He refuses to see Tractarians as the only "saviors" of the Church of England, and in contrast to Anglo-Catholic authors considers the period preceding the Oxford movement "not worse than many others" [19, p.16].

\section{The problems of the Oxford movement in general studies}

Only in the second half of the $20^{\text {th }}$ century the time of overt confessionalism passed, and a more objective approach to the research of Tractarianism began to prevail. Due to the multiplicity of works affecting various aspects of the Oxford movement, in this article we will limit ourselves to the consideration of two types of studies. First, these are sections devoted to the Oxford movement in various broader studies, primarily in the Church history. They are not always substantial, but what makes them remarkable is the fact that their authors tried to define the place of Tractarianism in the history of Anglicanism and analyze its impact on the subsequent development of the Church of England.

\footnotetext{
${ }^{1}$ A detailed analysis of the situation, with references to specific studies, is given.in the article of A. Atherstone [17].
} 
Eminent British historian N. Gash paid in his Ford Lectures, which were devoted to the problems of political development in the 1830-1850s, considerable attention to religious issues. The main significance of the Tractarians, according to Gash, lies not in the field of theology, but in the formation of an "anti- Establishment party within the Establishment" [20, p. 112]. The position of the Church of England as a national Church weakened. It became "less united, less fit to be entrusted with national tasks" [20, p.96].

In O. Chadwick's classical work on Victorian churches, the origins and main stages of the Oxford movement are considered. Focusing on the figure of Newman, Chadwick, like Gash, indicates the ambiguity of the movement's consequences for the Church of England, in particular, the weakening of spiritual unity [21, p. 229-231]. D. Bowen in his work on the history of the Victorian Church uses the term "counter-reformation" as a characteristic of the Oxford movement, believing that, at least initially, in the 1830s the Tractarians primarily sought to rid the Church of "tyranny of an Erastian" legislature" [22, p. 44]. But in general the Tractarian ideology, especially its theological aspects, did not gain "substantial influence in the Church of England" [22, p. 84]. He notes only one significant exception: the idea of justification for episcopacy by the doctrine of apostolic succession [22, p. 86-89]. It was accepted by most bishops of the Establishment and led to the assertion of a "higher doctrine of the Church," according to which it is "not an apanage of the State but a society with a spiritual authority of its own" [22, p. 375].

G. Parsons focuses in the first chapter of the work "Religion in Victorian Britain" on the desire of Tractarians to de-Protestantise the Church of England, which led to the undermining of doctrinal and theological consensus within the Established Church. As a result, if in the 1830s the question was "What do Anglicans believe?", then by 1900 it was replaced by the question "Which Anglicans?" [23, p. 31, 38, 62].

W. Gibson, in his generalizing work "Church, State and Society, 1760-1850," devoted only six pages out of two hundred to the analysis of the Oxford movement. In his opinion, the Tractarian ideas were too radical for most of the Anglican clergy, had no political support, and therefore remained marginal. The administration of the Church of England remained in the hands of the State, and this was also the failure of the Oxford theologians, who emphasized its divine character. The only undertaking in which the Tractarians and their followers were successful was the revival of church rituals and Gothic architecture [24, p. 137-143].

It should be noted that Gibson is one of the few modern researchers who believes that the influence of the Oxford movement on the Church of England was insubstantial. This position is shared, for example, by R. Pattison, who uses the term "failure" in evaluating the activities of Newman and his Tractarian associates [25, p. 9-19, 26].

S. Brown examines the Oxford movement within the framework of his comparative study of established churches in England, Scotland and Ireland in the first half of the $19^{\text {th }}$ century. Like many authors of such synthesizing works, Brown emphasizes that Tractarianism played the role of a "divisive force" in the Church of England. Beginning as a fight for spiritual independence of the Church, in the next stage, it was transformed into a movement for the revival of Church principles, and finally, emphasis was placed on the restoration of ancient and medieval devotion and the liturgy [26, p. 291-292]. Brown, following Y. Brilioth and P. Butler, who discovered similarities between the Oxford move-

\footnotetext{
${ }^{2}$ Erastianism - the doctrine of superiority of state to the church in ecclesiastical matters.
} 
ment and the Irvingite movement, later transformed into a separate Catholic Apostolic Church, offered a detailed comparative analysis of two religious groups. Brown emphasizes that both movements tried to revive the "Holy Catholic church," but Irvingites hoped to produce it through a revival of the Spirit gifts, and the Oxford movement - through the idea of apostolic succession [26, p. 291-292].

In 2002, a revised and expanded edition of the book of Anglican theologian P. Avis "Anglicanism and the Christian Church" appeared, in which an analysis of the ideology of Tractarianism was much more detailed than in the 1989 edition. For Avis, as for Brown, Tractarianism is a "divisive force" in Anglicanism. Until 1833 the Erastian paradigm dominated in the Church of England, based on the idea of its Protestant and Reformed character. The Oxford movement subverted the prevailing consensus, proposing instead a new foundation for Anglican identity: apostolic succession and spiritual independence from the state [27, p. 180-181]. Avis believes that to a certain extent, the Tractarians succeeded in the de-Protestantisation of Anglicanism, but their protection of the hierarchical order both in the church and in society as well as a narrow understanding of Catholicism resulted in the failure to establish a new paradigm [27, p. 182-184].

\section{Special studies of Oxford movement}

The second and certainly the most significant group of works are the books devoted to the Oxford movement as a whole. These are studies of both a theological and historical nature. First of all, it should be noted that there were almost five hundred pages of

the book by the American researcher and Roman Catholic priest M. O'Connell which look at the Oxford movement [28]. Conceptually and chronologically, O'Connell remains within the bounds set by R. Church, but relies on an incomparably wider variety of sources. To this day, O'Connell's work remains the most detailed description of the event-driven side of the movement. O'Connell analyzed the background of the emergence of Tractarianism and the political context in which it originated. Confessionalism in O'Connell's work is present indirectly rather than directly, in terms of, for example, paying significant attention to Newman's figure disproportionately with other Tractarians.

The major British expert in the history of European religiosity O. Chadwick devoted a special study to the problems of Tractarianism. In this study, "The Mind of the Oxford Movement," he describes it as "more a movement of the heart than of the head." Defending, unlike many of his predecessors, the thesis of the continuity of the Tractarians in relation to the traditional High churchmen, he sees a major difference in the latter's lack of emotion and commitment to cold schematism [29, p.28]. The movement, according to Chadwick, changed the external face and the internal spirit of the Church of England. Its theological achievements are not as weighty, since many particular doctrines (for example, baptismal regeneration) were not approved by the Established Church [29, p. 58].

American researcher J. Griffin analyzes the political and social thought of the three original leaders of the Oxford movement, namely, Keble, Froude and Newman. The movement as a whole is regarded by him as revolutionary and anti-Protestant in its direction [30, p. 146]. In the book, and especially in the previously published article [31], he stresses anti-Erastianism of the starting years of the movement ("radical phase"), which went as far as desiring disestablishment of the Church of England. Pusey, who according to Griffin 
did not share such views, is viewed by him as a companion rather than an active participant of the movement in its initial phase [30, p. 47-57].

The death in 1836 of the main "radical" R.H. Froude, the gradual disappearance of the threat of disestablishment of the Church of England, which seemed real in the early 1830s, and the departure of Newman to the Roman Catholic Church led to the weakening of radicalism and the idea of preserving the Church-state union became dominant [30, p. 2, 137-146]. The next, Anglo-Catholic phase of the movement, which lasted from 1845 to the end of the 19th century, was characterized by moderation and rejection of "basic doctrinal idea of 1833, apostolic succession" [30, p. 121].

J. Rowlands tasked himself with the duty of overcoming the view of Tractarianism as divorced from the realities of their world, considering the political and social thought as an inherent part of its theology [32, p. IX-X]. Unlike Griffin, Rowlands does not consider Tractarians as neither radicals nor revolutionaries. He emphasizes that Keble, Froude and Newman were not supporters of social reforms and considered the traditional hierarchical model of society God-given. They were united by a unanimously negative attitude to rationalism, utilitarianism, liberalism, and Erastianism [32, p. 223-226]. At the same time, Rowlands agrees with Griffin that the idea of the spiritual independence of the Church of England was one of the central ones in the movement. It was supported, though not to the same degree, by all its leaders and Froude even saw theocracy as the ideal [32, p. 229-230].

In 1994, the monograph of P. Nockles was published, whose focus is on the relationship between the Oxford movement and the High Church tradition. Nowadays, Nockles, due to his numerous publications, is perhaps the most significant modern expert in the problems of the Oxford movement, and a rare research on Tractarianism does not have references to his works.

Relying on a significant amount of documentary materials, Nockles seeks to show that the Oxford movement, with all its originality, should be considered as a part of the High Church tradition. While Chadwick focused on the development of the ideas of the 17-century Caroline divines by the Tractarians, Nockles offers a rehabilitation of the High Church leaders at the turn of the $18-19^{\text {th }}$ century. Unlike Avis, he does not consider it possible to speak of the absolute domination of the Erastian paradigm in the Church of England at this time, emphasizing in particular that not all High Church leaders were Erastians [3, p. 60-61].

Nockles sees the specificity of Tractarianism primarily in the denial of the heritage of the Reformation and the Protestant character of the Church of England. While acknowledging the destruction of the pre-existing Anglican consensus by the Oxford movement, Nockles warns against exaggeration of its divisive impact. The parties in the Church of England existed even before the start of the Oxford movement, and its appearance did foreclose the possibilities of theological compromises and cooperation between various groups [3, p. 310-321]. On the whole, the Tractarianism suffered failure in the short term, but "the Movements breadth of spiritual influence overrode its increasing tendency towards a churchy sectarianism" [3, p. 327].

Studying the relationship between Tractarians and the traditional High Churchmen, Nockles expresses his opinions on a wide range of issues related to the history of the Oxford movement. Thus, he proposes to abandon 1833 as its starting point, and dates the birth of the movement to 1829 [3, p.69]. Nockles does not believe that Tractarians seriously considered the possibility of the separation of the Church of England from the state. 
In his opinion, the idea of disestablishment was only a "tactical weapon" used in situations of crisis [3, p. 103].

Another eminent contemporary researcher of the problems of the Oxford movement, G. Herring, has published two monographs. The first, "What was the Oxford movement?" appeared in 2002. In the section of the book that analyzes events prior to 1845, Herring, emphasizes the originality of the movement ("a fundamental break with Anglican past" $[33$, p. 44], does not at the same time put forward any fundamentally new considerations. Such points are fully present, however, in the last chapters of the study.

Analyzing Newman's gradual advancement towards Roman Catholicism (which he very aptly calls "another movement... within... the Oxford movement") [33, p. 62], Herring strongly rejects the widespread idea, going back to R. Church, that the departure of the leader of the Oxford movement and some of his supporters to Rome was a "catastrophe"; to him this idea is the "myth of 1845 " [33, p. 65-66]. In his opinion, the center of the Tractarian movement simply moved to the parishes, and most priests who supported the ideas of the Oxford movement at the same time never had personal contact with Newman and his friends [33, p. 66-69].

According to Herring's calculations, the number of Tractarian parish priests increased from 141 in 1845 to 442 in 1870, although overall they made up no more than $5 \%$ of the Anglican parish clergy. Nevertheless, it was an influential minority that became the vanguard of reform in the Anglican parishes, asserting new standards of holiness, for example daily divine services and weekly communion [33, p. 80-89].

Herring's second monograph is almost entirely devoted to the events that took place after 1845. Compared to the first book, the issues of the influence of the Tractarian clergy on changes in parish life are reviewed and analyzed here in greater detail. The central idea of the second monograph is the refutation of the thesis, shared by many scholars on the problems of Tractarianism, in particular N. Yates [34], that the Ritualists movement of the middle and second half of the XIX century was a direct continuation of the Oxford movement. According to Herring, the Ritualists "distorted the essential nature of the Oxford movement." Whereas the Tractarians appealed to the heritage of the Ancient Church and sought to preserve the unity of the Church of England, the Ritualists turned to "fantasized Middle Ages," and, through their liturgical experiments, which raised objections from the original leadership of the Oxford movement, acted with "sectarian exclusiveness" [35, p. 245]. Herring also blames the Ritualists for Tractarians' failure to achieve their main purpose - the approval of the concept of the essentially Catholic nature of the Church of England. It is due to their resurgence in the 1860s that the Oxford movement, in spite of partial successes, can be overall considered a "relative failure" [35, p. 250].

The work of Canadian specialist C. Brad Faught, published in 2003, did not become a significant milestone in the historiography of the Oxford movement. At the same time, it should be noted that the task he set for himself - to prepare "a modern, synthetic, and accessible account" of Tractarianism [36, p. XI] — was accomplished. C. Brad Faught mainly remains within the framework of the traditional chronology of the movement, focusing mostly on the events of 1833-1845, stressing that precisely at that time the impact of the original leaders of Tractarianism was the strongest and most important [36, p. X]. Paradoxically, the most interesting sections of the book are those in which the author goes beyond 1845 and touches upon poorly researched topics such as the impact of Tractarianism on Anglican women (for example, novelist Charlotte Yonge and poet Christina Rossetti; 
also discussed the role of Pusey in the formation of Anglican sisterhoods) [36, p. 108-113] and missionary activity in Africa [36, p. 127-138].

S. Skinner devoted his research to the analysis of the social aspects of Tractarianism. At the same time, his monograph is a holistic study of the Oxford movement, covering a wide range of issues. Thus, the Tractarian concept of church-state relations is afforded detailed consideration. Skinner emphasizes that Oxford divines were not supporters of the separation of church and state. However, in defending the need to preserve the churchstate union they were close to the idea of theocracy, awarding the Church of England a leading role and insisting that the state should follow its lead [4, p. 83-135].

Studying the social concepts of the movement, Skinner focuses on the refutation of the widespread view of its "overworldliness." Actively introducing new sources, which was almost neglected by the researchers, (first of all, "The British Critic" magazine, which was controlled in 1838-1843 by Newman and his associates, as well as works by now forgotten writers F. Paget and W. Gresley, who were close to the Oxford movement), Skinner argues that Tractarians preferred a paternalist model of society. They criticized a new Poor Law (1834) as an intervention of the utilitarian state in parish life, preferring traditional Christian charity [4, p. 280-296].

Tractarians not only decried the negative aspects of capitalism, but also saw an alternative in turning the Anglican parish into a "sacred community" where the rich and the poor would be closely connected, participating in religious festivals, games, sitting in the same church building, liberated from the private pews, traditional at the time [4, p. 136-189]. Thus, Skinner believes, we can talk about the existence of a definite Tractarian social theology.

J.Pereiro focused on the analysis of the theological aspects of the Oxford movement. The key to understanding the Tractarian movement, in his opinion, is the concept of ethos. It has never been systematically formulated by Oxford divines, but, as the subtitle of Pereiro's work suggests, lies "at the heart of Tractarianism." Pereiro defines ethos as "a moral temper involving openness to God's action in the soul" [37, p. 109]. Ethos includes the theory of religious knowledge, based on holiness of life leading to right faith. Pereiro insists on the original and radical nature of the Oxford movement, emphasizing that its communal ethos was very different from ethos of High Churchmen of the early $19^{\text {th }}$ century.

Firstly, all Tractarians tried to recover the Catholic ethos for the Church of England, based on the conception of Antiquity as a rule of faith ("patristic fundamentalism") [37, p. 234]. The Tractarian struggle with Evangelicals, secularizing state, and legacy of Reformation may be interpreted as a fight against a corrupted and faulty ethos. But one important question remained: which tribunal will issue verdicts about what is right or wrong to interpret in the heritage of the early Church [37, p.235]? It was the search for such authority that eventually led Newman to Rome. But other Tractarians did not come to such radical conclusions, focusing on the implementation of the discovered Catholic doctrine [37, p. 200-237].

The latest work to date, specifically dedicated to the problems of development of Oxford movement, is impressive both in its scope and in its content. The more than 600-page collective monograph consists of 42 chapters, divided into 8 thematic blocks [10]. The volume contains contributions from 34 authors, among whom there are many of those who in the last three decades devoted a special monograph to the Oxford movement P. Nockles, J.Pereiro, S. Skinner and G. Herring. The first two, as well as S. Brown, edited the volume. 
Along with fairly customary subjects (interrelation with High Church tradition and Evangelicals, main ideas of "Tracts for the Times," etc.) the publication also addresses such specific questions such as the movement's influence on the development of church music and hymnody, poetry, fiction, and the Pre-Rafaelite Brotherhood. The authors of the chapters mainly use, although in a revised form, their previously published materials and therefore any original and highly unexpected innovative concepts are not put forward here. Evidence of a certain scholarly consensus that has developed to date can be found in the "Introduction" written by three editors of the volume. Firstly, 1833 is singled out here as the preferred date for the movement's inception. Secondly, the movement is called revolutionary. Thirdly, 1845 is designated as the completion of the actual Oxford stage of Tractarianism, further developed in the form of Anglo-Catholicism. Fourthly, questions about the date of the movement's end and its relationship with Ritualism is left open [10, p.2-6]. Probably, the "Oxford Handbook" can be considered as the end of the stage in the study of Tractarianism, which began in the middle of the last century, marked by the emergence of a large number of studies covering the Oxford movement as a whole.

\section{Conclusion}

In summary, it can be stated that tremendous progress has been made in the study of the Oxford movement and its consequences in the last three to four decades. Overt confessionalism has long gone, a tremendous factual base has been accumulated, and new sources are being introduced into circulation. Recently, along with the study of relationships and mutual influences of Tractarianism, Evangelism, Ritualism, and Irvingism, another important historiographical trend has emerged: analysis of the international aspects of the Oxford movement, its perception both in English-speaking countries and beyond. This tendency is most fully expressed in a collective monograph "The Oxford Movement: Europe and the Wider World, 1830-1930" [38]. This study includes chapters on the reception of the Oxford movement in Germany, Belgium and France, and only a few words are mentioned in this respect about Russia. In our opinion, the study of the Russian dimension of Tractarianism, along with questions about the perception and assessment of the Oxford movement by the press, public opinion, and various social groups of English society, should in the near future be the center of researchers' attention. In any case, we should expect first of all an in-depth study of more specific issues.

\section{References}

1. Crumb, L. (2009), The Oxford Movement and Its Leaders: A Bibliography of Secondary and Lesser Primary Sources, $2^{\text {nd }}$ ed., Scarecrow Press, Lanham.

2. Santos Sotelo, V. (1988). The leading Interpretations on the Significance and Nature of the Oxford movement, Abstract of PhD. dissertation, University of Navarra, Pamplona.

3. Nockles, P. B. (1994), The Oxford Movement in Context: Anglican High Churchmanship, 1760-1857. Cambridge University Press, Cambridge, UK.

4. Skinner, S. (2004), Tractarians and the 'condition of England': the social and political thought of the Oxford Movement, Oxford University Press, Oxford.

5. Church, R.W. (1897), The Oxford Movement: Twelve years 1833-1845, Macmillan and Co, London.

6. Palmer, W. (1843), A Narrative of Events connected with the publication of the Tracts for the Times, John Henry Parker, Oxford, UK.

7. Palmer, W. (1883), A Narrative of Events connected with the publication of the Tracts for the Times, Rivingtons, London. 
8. Newman, J.H. (1864), Apologia pro Vita Sua, Appleton and Co, New York.

9. Liddon, H. P., Life of Edward Bouverie Pusey, vols. 1-4, Longmans, London.

10. Brown, S., Nockles, P. and Pereiro, J. (ed.) (2017), The Oxford Handbook of the Oxford movement, Oxford University Press, Oxford.

11. Keble, J. National Apostasy Considered in a Sermon Preached in St. Mary's, Oxford, before His Majesty's Judges of Assize, on Sunday, July 14, 1833 (1833), J. H. Parker, Oxford.

12. Ollard, S. (1915), A Short History of the Oxford Movement, A. R. Mowbray and Co, London.

13. Walsh, W. (1898), The Secret History of the Oxford Movement, Swan Sonnenschein, London.

14. Walsh, W. (1900), The History of the Romeward Movement in the Church of England, 1833-1864, James Nisbet, London.

15. Heroes of the Catholic Revival (1933), Catholic Literature Association, London.

16. Morse-Boycott, D. (1933), Lead, Kindly Light: Studies of the Saints and Heroes of the Oxford Movement, Macmillan, New York.

17. Atherstone, A. (2013) "Evangelicals and the Oxford Movement Centenary", Journal of Religious History, vol. 37, no. 1, pp. 98-117.

18. Dawson, C. (1945), The Spirit of the Oxford Movement, Sheed and Ward, London.

19. Brilioth, Y. (1933), The Anglican Revival: Studies in the Oxford Movement, Longmans, Green, London.

20. Gash, N. (1965), Reaction and Reconstruction in English Politics, 1832-1852. The Ford Lectures Delivered in The University of Oxford in the Hilary Term 1964, Clarendon Press, Oxford.

21. Chadwick, O. (1987), The Victorian Church, vol. 1, SCM Press Ltd, UK.

22. Bowen, D. (1968), The Idea of the Victorian Church: a Study of the Church of England, 1833-1889, McGill University Press, Montreal.

23. Parsons, G. (1988), "Reform, Revival and Realignment: The Experience of Victorian Anglicanism", in Parsons, G. (ed.), Religion in Victorian Britain, vol. I Traditions, Manchester University Press, Manchester, pp. 15-65.

24. Gibson, W. (1994), Church, State and Society, 1760-1850, Macmillan, London.

25. Pattison, R. (1991), The Great Dissent. John Henry Newman and the Liberal Heresy, Oxford University Press, Oxford.

26. Brown, S. (2001), The National Churches of England, Ireland and Scotland, 1801-1846, Oxford University Press, Oxford.

27. Avis, P. (2002), Anglicanism and the Christian Church. Theological Resources in Historical Perspective, Continuum, London.

28. O'Connell, M. (1969), The Oxford Conspirators: A History of the Oxford Movement, 1833-1845, Macmillan, London.

29. Chadwick, O. (1960), The Mind of the Oxford Movement, A \& C Black Publishers Ltd, London.

30. Griffin, J.R. (1980), The Oxford Movement: A Revision. Christendom Publications, Front Royal, Virginia.

31. Griffin, J.R. (1976), “The Radical Phase of the Oxford Movement", Journal of Ecclesiastical History, vol. 27 , no. 1 , pp. $47-56$.

32. Rowlands, J. (1989), Church, State and Society. The Attitudes of John Keble, Richard Hurrell Froude and John Henry Newman, 1827-1845, Churchman Publishing Ltd, Worthing.

33. Herring, G. (2002), What was the Oxford Movement?, Continuum, London.

34. Yates, N. (1983), The Oxford Movement and Anglican Ritualism, The Historical Association, London.

35. Herring, G. (2016), The Oxford Movement in Practice: The Tractarian Parochial Worlds from the 1830 s to the 1870 s, University Press, Oxford.

36. Brad Faught, C. (2003), The Oxford Movement. A Thematic History of the Tractarians and their Times, The Pennsylvania State University Press, University Park.

37. Pereiro, J (2008). Ethos and the Oxford Movement: At the Heart of Tractarianism, University Press, Oxford.

38. Brown, S., Nockles, P. (eds.), (2012), The Oxford Movement: Europe and the Wider World, 1830-1930, Cambridge University Press, Cambridge.

Authors' information:

Received: November 29, 2018

Accepted: June 13, 2019

Mikhail S. Stetckevich — PhD, Associate Professor; m.steckevich@spbu.ru

Tatiana V.Chumakova - Dr. Sci in Philosophy, Professor; t.chumakova@spbu.ru

Sergei Frolov — PhD in History and Religious Studies, Professor; sfrolov@smu.edu 


\title{
Изучение Оксфордского движения: основные историографические проблемы и тенденции
}

\author{
М. С. Стеикевич 1 , Т. В. Чумакова ${ }^{1}$, С. Фролов \\ ${ }^{1}$ Санкт-Петербургский государственный университет, \\ Российская Федерация, 199034, Санкт-Петербург, Университетская наб., 7-9 \\ ${ }^{2}$ Южно-Методистский университет, \\ США, Техас, 75275, Даллас, ул. Роберта С. Хаэра, 6424
}

Для цитирования: Stetckevich M. S., Chumakova T. V., Frolov S. The Oxford movement studies: main historiographical problems and trends // Вестник Санкт-Петербургского университета. Философия и конфликтология. 2019. Т. 35. Вып. 4. С. 662-673. https://doi.org/10.21638/spbu17.2019.411

В статье анализируются основные тенденции историографии Оксфордского (трактарианского) движения в Церкви Англии, оказавшего огромное влияние не только на ее последующее развитие, но и на эволюцию англиканства в целом. Цели статьи: выделить ключевые тенденции в развитии историографии Оксфордского движения, обозначить круг проблем, изучаемых исследователями, сосредоточив внимание на рассмотрении наиболее дискуссионных вопросов. В задачу статьи входит как аналитический разбор работ авторов, рассматривавших историю Оксфордского движения в контексте эволюции Церкви Англии (Н. Гэш, О. Чедвик, Н. Эвис, С. Браун), так и исследователей, в фокусе внимания которых был сам феномен трактарианства (О’Коннел, Дж. Гриффин, Дж. Роуландс, П.Ноклс, Дж. Перейро, Дж. Херринг). Авторы статьи применяли проблемно-хронологический и сравнительный методы, позволяющие представить основные историографические достижения в их динамическом развитии. Делается вывод о том, что конфессионализм, выражавшийся в представлении трактарианских лидеров или как «спасителей» Церкви Англии, или как «предателей», стремившихся привести ее в лоно Римско-католической церкви, в настоящее время полностью преодолен. Достигнут значительный исследовательский консенсус по таким вопросам, как дата возникновения движения, его революционный характер, взаимосвязь с высокоцерковной традицией, серьезное влияние на последующую эволюцию англиканства. Дискуссионным остается вопрос о взаимосвязи трактарианства с движением ритуалистов второй половины XIX в. Дальнейшие перспективы изучения Оксфордского движения связаны в первую очередь с анализом его международного измерения (в частности, российского), его восприятия британским обществом.

Ключевые слова: Оксфордское движение, трактарианство, Церковь Англии, историография, англиканство, религиоведение.

Статья поступила в редакцию 29 ноября 2018 г.; рекомендована в печать 13 июня 2019 г.

Контактная информация:

Стецкевич Михаил Станиславович - канд. ист. наук, доц.; m.steckevich@spbu.ru Чумакова Татьяна Витаутасовна - д-р филос. наук, проф.; t.chumakova@spbu.ru Фролов Сергей - канд. ист. наук и религиоведения, проф.; sfrolov@smu.edu

* Подготовлено при поддержке гранта РФФИ № 18-011-00241 «От эрастианизма к трактарианизму: Церковь Англии в конце XVIII — первой половине XIX в.». 